DOI: https://doi.org/10.24127/ajpm.v10i4.4366

\title{
STUDENT'S MATHEMATICAL PROBLEM-SOLVING ABILITY WITH MATHEMATICAL RESILIENCE AND METACOGNITION SKILLS: A QUANTITATIVE ANALYSIS
}

\author{
Ujiati Cahyaningsih ${ }^{1}$, Dede Salim Nahdi ${ }^{2 *}$, Mohamad Gilar Jatisunda ${ }^{3}$, \\ Vici Suciawati ${ }^{4}$ \\ ${ }^{1,2,3,4}$ Universitas Majalengka, Indonesia \\ *Corresponding author. \\ E-mail: $\quad$ ujiati@unma.ac.id ${ }^{\text {l) }}$ \\ salimnahdi@unma.ac.id $^{2 *}$ \\ gjatisunda@unma.ac.id $\left.{ }^{3}\right)$ \\ vicisuciawati@unma.ac.id
}

Received 20 October 2021; Received in revised form 16 December 2021; Accepted 19 December 2021

\begin{abstract}
Abstrak
Beberapa hasil studi menunjukkan kemampuan pemecahan masalah siswa masih rendah, sehingga diperlukan upaya guru untuk meningkatkannya. Penelitian ini memiliki fokus untuk meningkatkan kemampuan pemecahan masalah matematis siswa berdasarkan faktor dalam diri siswa sendiri, yaitu Mathematical Resilience dan kemampuan metakognisi. Penelitian ini menggunakan pendekatan kuantitatif, dengan jenis penelitian expost facto. Populasi dalam penelitian ini adalah siswa Sekolah Dasar di Kabupaten Majalengka dengan sampel 30 orang siswa kelas V SDN Jatipamor I Kecamatan Panyingkiran. Instrumen pengumpulan data dalam penelitian ini menggunakan soal tes dan angket. Data yang telah terkumpul selanjutnya dianalisis dengan menggunakan analisis of varian. Hasil penelitian menunjukkan bahwa kemampuan pemecahan masalah siswa yang memiliki Mathematical Resilience dan metacognition skill tinggi lebih baik dibandingkan siswa yang lain. Dengan demikian dapat disimpulkan bahwa Mathematical Resilience dan metacognition skill memiliki pengaruh yang sangat besar terhadap kemampuan siswa dalam memecahkan masalah-masalah matematika. Hasil penelitian ini berkontribusi dalam memberikan informasi terkait pentingnya ketahanan matematis dan kemampuan metakognisi siswa dalam pembelajaran matematika sehingga guru di sekolah dapat memberikan perhatian khusus terhadap kedua kemampuan ini agar siswa mampu memecahkan masalah matematika.
\end{abstract}

Kata kunci: ketahanan matematika; metakognitif; pemecahan masalah matematika.

\begin{abstract}
Several studies show that students' problem-solving abilities are still low, so teacher efforts are needed to improve them. This research has a focus on improving students' mathematical problem solving abilities based on factors within the students themselves, namely Mathematical Resilience and metacognition abilities. This study uses a quantitative approach, with the type of expost facto research. The population in this study were elementary school students in Majalengka Regency with a sample of 30 fifth grade students at SDN Jatipamor I, Panyingkiran District. The data collection instrument in this study used test questions and questionnaires. The data that has been collected is then analyzed using the analysis of variance. The results showed that the problem solving abilities of students who had high Mathematical Resilience and metacognition skills were better than other students. Thus it can be concluded that Mathematical Resilience and metacognition skills have a very large influence on students' ability to solve mathematical problems. The results of this study contribute to providing information regarding the importance of mathematical resilience and students' metacognitive abilities in learning mathematics so that teachers in schools can pay special attention to these two abilities so that students are able to solve mathematical problems.
\end{abstract}

Keywords: mathematical resilience; metacognitive; mathematical problem solving.

This is an open access article under the Creative Commons Attribution 4.0 International License 


\section{INTRODUCTION}

Problem solving in mathematics helps students to experience how to solve problems in everyday life by applying their mathematical knowledge and skills (Osman et al., 2018). Many problems in everyday life are solved using mathematics (Aljaberi \& Gheith, 2016). By teaching problem solving skills, students can develop and apply their mathematical abilities in dealing with real-life problems (Gurat, 2018).

Problem solving in mathematics is an attempt to achieve certain results by applying non-standard methods, therefore it takes a lot of effort to achieve the desired results (Schoenfeld, 2013). Problem solving is considered a fundamental aspect of education (Rott, 2020; Tambunan, 2019). Problem solving helps students in dealing with real-life situations. In learning mathematics, problem solving ability is the main goal (Surya \& Putri, 2017; Wilson et al., 2011). These skills help individuals in developing logical thinking and improve decision-making skills by applying logical processes such as induction and deduction, as well as applying algorithms needed to solve everyday situations. (Taplin, 2004). According to Polya (2004) in solving a problem, there are several stages that must be passed, including (1) Understanding the problem; (2) Planning a settlement strategy; (3) Implementing the settlement; (4) Reexamine the results obtained. These four stages are interrelated links. When students have difficulty at one stage it will be difficult to do the next stage.

Students need to have the ability to solve mathematical problems because it is a necessity in mathematics curricula around the world (Liljedahl et al., 2016). Problem solving abilities can help students overcome the difficulties they face to achieve the expected goals (Putri et al., 2019; Sumartini, 2018). Therefore, in mathematics learning activities the teacher needs to introduce students to mathematical problems, because by facing problems students will be required to think intensively and creatively in solving the problems they face (Elita et al., 2019).

However, several studies reveal the fact that students' mathematical problem solving abilities are still not satisfactory. Problem solving in mathematics has provided difficulties and frustrations for a large number of students (Bluman, 2004; Sharp \& Shih Dennis, 2017; Verschaffel \& De Corte, 1993). This condition was revealed from several previous research results, including research conducted by Arta et al. (2020), Amaliah et al. (2019) Kristianto \& Rahayu (2020), Lestari et al. (2020), Nikmah et al. (2020), Psycharis \& Kallia (2017), Saygilı (2017), Sejati \& Koeswanti (2020), and Sintawati et al. (2020). Several studies have been conducted to seek to improve students' problem-solving abilities, including by applying appropriate learning models or strategies, such as problem-based learning (Marlina et al., 2018) (Noviantii et al., 2020) (Sariningsih \& Purwasih, 2017), Realistic Mathematical Education (Febriyanti \& Irawan, 2017), Creative Problem Solving Learning Model (Muhammad et al., 2018), Discovery learning model (Jana \& Fahmawati, 2020), and Guided Discovery Method (Qamardhani \& Surya, 2018). Other research also seeks to improve problemsolving abilities through development research, including the development of problem-based mathematics learning tools (Nasution et al., 2017) (Yustianingsih et al., 2017), Development of ethnomathematics- 
based e-modules (Utami et al., 2018), Development of HOTS-based Teaching Materials (Anisah \& Lastuti, 2018), and Discovery Learning-Based Mathematics Learning Device Development (Rahmiati et al., 2018).

If examined further, previous studies have made more efforts to improve mathematical problem-solving abilities by paying attention to external factors, such as the application of models, strategies, or the development of tools and learning, while internal factors have not become the attention of researchers. Even though there are many factors from within students that affect students' ability to solve mathematical problems, factors from within students include Mathematical Resilience and metacognitive abilities.

In dealing with mathematical problems, in addition to having to think at a high level, students are also required to work hard, don't give up easily, and have self-restraint. Students who have self-restraint tend to avoid feelings of anxiety and fear. Therefore, it is necessary to be diligent and tough in learning mathematics or called mathematical resilience (JohnstonWilder \& Lee, 2014). A student needs to have the ability to overcome, and improve himself from the mathematics anxiety he faces. A student needs to have Mathematical Resilience in order to be able to survive the mathematical problems they face. Having good Mathematical Resilience skills will lead to different beliefs about mathematics (Young-Loveridge, 2010).

Another aspect that students need to have to be able to solve mathematical problems is metacognition ability. PeñaAyala \& Cárdenas (2015) explained that cognition means to know, and elaborated on this by suggesting cognition involves an individual's perception and comprehension of the world, and how he/she behaves in that context. Metacognition is a form of ability to look at himself so that what he does can be controlled optimally (Abrar, 2018; Iskandar, 2014; Wicaksono \& Akhdinirwanto, 2013). With this kind of ability, it is possible for a person to have a high ability to solve problems. The success of students in solving problem solving, among other things, really depends on their awareness of what students know and how to do it (Pujiank et al., 2016). Students with good metacognitive abilities can know themselves as individuals who learn and how they control and adjust their behavior. Students need to be aware of their strengths and weaknesses.

\section{RESEARCH METHODS}

This study uses a quantitative approach, namely the scientific approach used to view a reality that can be classified, concrete, observable and measurable, the relationship of the variables is causal where the research data is in the form of numbers and the analysis uses statistics. This research is ex post facto, because in the study no treatment or manipulation was made on the research variables, but only the symptoms that had occurred to the respondents before this research was conducted. In other words, in this study no experimental class was given treatment, but students were directly given a test to measure the research variables, namely mathematical problem solving ability, mathematical resilience, and metacognition ability.

The population in this study were elementary school students in Majalengka Regency. The sample in this study was selected randomly by purposive sampling technique. With this sampling technique, the sample in this 
study was 30 students of class V at SDN Jatiapmor I, Panyingkiran District.

Data collection techniques used in this study were tests and questionnaires. The test is given to students in the form of non-routine description questions to determine students' ability to solve mathematical problems. The questionnaire was given to students to find out the mathematical resistance and cognitive abilities of students. The data from the questionnaire results of mathematical endurance and students' cognitive abilities were classified into three categories of high, medium, and low. The data on the results of the mathematical problem solving ability test were analyzed based on the level of mathematical resilience and metacognition skills using the analysis of variance.

\section{RESULTS AND DISCUSSION}

The data from this study were obtained from the score of the problemsolving ability test through the provision of questions. Problem solving ability test questions are designed to use contextual problems to measure students' ability to solve non-routine problems. Before analyzing the results of non-routine problem tests, students are first distributed based on the level of mathematical resilience and metacognition skills, namely high, medium, and low levels. Based on the measurement results of mathematical resilience and metacognition skills, data on the number of students was obtained based on the level of mathematical resilience and metacognition skills in high, medium, and low categories as can be seen in Table 1 .

Table 1. The number of students based on the level of mathematical resilience and metacognition skills

\begin{tabular}{llc}
\hline Variabel & Level & N \\
\hline \multirow{3}{*}{ Mathematical Resilience } & high & 9 \\
& medium & 10 \\
& low & 11 \\
Metacognition s skill & high & 8 \\
& medium & 13 \\
& low & 9 \\
\hline
\end{tabular}

The results of the mathematical problem solving ability test, based on each level of mathematical resilience and metacognition skills, are descriptively presented in Table 2.

Table 2. Results of mathematical problem solving ability tests based on the level of mathematical resilience and metacognition skills

\begin{tabular}{lccrc}
\hline Mathematical Resilience & Metacognition skill & Mean & Std. Deviation & N \\
\hline \multirow{3}{*}{ High } & High & 89.8000 & 1.30384 & 5 \\
& Medium & 80.5000 & 4.43471 & 4 \\
& Total & 85.6667 & 5.67891 & 9 \\
Medium & High & 83.5000 & 2.12132 & 2 \\
& Medium & 80.4000 & 2.19089 & 5 \\
& Low & 78.3333 & 1.52753 & 3 \\
& Total & 80.4000 & 2.59058 & 10 \\
Low & High & 80.0000 & & 1 \\
& Medium & 78.7500 & .95743 & 4 \\
& Low & 72.8333 & 3.43026 & 6 \\
Total & Total & 75.6364 & 4.08100 & 11 \\
& High & 87.0000 & 4.20883 & 8 \\
& Medium & 79.9231 & 2.72218 & 13 \\
& Low & 74.6667 & 3.93700 & 9 \\
\hline
\end{tabular}


DOI: https://doi.org/10.24127/ajpm.v10i4.4366

From the data presented in Table 2 , it can be seen that the average result of the highest mathematical problem solving ability of 89.8000 was obtained by the group of students with high Mathematical Resilience and high metacognition skills. There is also the lowest average test result is 72.8333 obtained by the group of students with low levels in Mathematical Resilience and metacognition skills. From these results, it is known that the group of students who have high mathematical resilience and metacognitive ability with the highest score obtained high math problem solving ability test results as well. On the other hand, the group of students with low math resistance and metacognitive ability got the lowest test results. Thus, descriptively, mathematical resilience and metacognitive ability affect students' ability to solve non-routine math problems.

To determine the effect of Mathematical Resilience and metacognition skills on students' problem solving abilities, a two-way analysis of variance was performed. The results of the two-way analysis of variance data processing are presented in Table 3.

Table 3. Analisis of varian

\begin{tabular}{lrrrrr}
\hline \multicolumn{1}{c}{ Source } & $\begin{array}{c}\text { Type III Sum of } \\
\text { Squares }\end{array}$ & df & $\begin{array}{c}\text { Mean } \\
\text { Square }\end{array}$ & F & \multicolumn{1}{c}{ Sig. } \\
\hline resilience & 113.050 & 2 & 56.525 & 7.984 & .002 \\
metacogition & 136.585 & 2 & 68.292 & 9.646 & .001 \\
resilience * metacogition & 70.539 & 3 & 23.513 & 3.321 & .039 \\
\hline
\end{tabular}

Based on Table 3, it can be seen that the mathematical problem solving ability of students with mathematical resilience obtained a p-value (sig) of $0.002<0.05$, so there are differences in students' mathematical problem solving abilities based on mathematical resilience levels (high, medium, and low). Students with high mathematical resilience get the highest average scores compared to medium and low levels. Thus, the problem solving ability of students with high mathematical resilience is better than that of medium and low mathematical resilience.

Students' mathematical problem solving abilities with metacognition skills obtained p-value (sig) of 0.001 < 0.05 , so there are differences in students' mathematical problem solving abilities based on metacognition skill levels (high, medium, and low). Students with high metacognition skills get the highest average scores compared to medium and low levels. Thus the problem solving ability of students with high metacognition skills is better than those with medium or low metacognition skills.

The interaction between Mathematical Resilience and metacognition skills on mathematical problem solving abilities obtained $\mathrm{p}$ value (sig) of $0.039<0.05$, so there is an interaction between Mathematical Resilience and metacognition skills on mathematical problem solving abilities. The existence of this interaction shows that Mathematical Resilience and metacognition skills together have a significant influence on students' mathematical problem solving abilities.

From the results of the answers of students who have high Mathematical Resilience and metacognition skills, the difficulties experienced are not too 
significant when compared to the answers of students who have low Mathematical Resilience and metacognition skills. Students who have high resilience and metacognition skills are able to answer mathematical problem solving ability tests well and achieve systematic steps in solving problems. They are able to explain the steps for solving problems on each question they have worked on confidently, clearly and in detail. The results of the answers of students who have low Mathematical Resilience and metacognition skills have difficulty in understanding the problems that exist in the questions and determine strategies to solve problems, this is due to a lack of understanding/mastery of concepts in the material being tested and students cannot solve these problems in accordance with the procedure. the solution. The lack of mastery of this concept causes students to fill in the formula that they think is right without thinking about whether the answer is right or wrong. They are less skilled in answering mathematical problem solving tests, this is evidenced by their lack of accuracy in answering questions, they tend to give up when faced with difficult questions and are reluctant to check again if they believe that the questions they are doing are wrong. Some questions haven't even reached systematic steps in solving problems.

From the results of the study, it was found that Mathematical Resilience had an effect on increasing students' problem solving abilities. This is because students who have self-restraint tend to avoid math anxiety so that they get better results in solving non-routine questions. This is in accordance with research conducted by Johnston-Wilder et al. (2015) which states that students who have resilience are more effective when facing difficulties in mathematics. This finding also supports research conducted by Attami et al. (2020) which states that students with high levels of mathematical resilience are able to face and overcome challenges and negative situations related to the problem solving process because they are able to train themselves. In addition, metacognition skills also affect the improvement of students' problem solving abilities. This is in accordance with research of (Alzahrani, 2021) which states that metacognition must be prioritized to increase students' awareness of the learning process. This is because conscious reflection allows students to develop the ability to choose the most appropriate strategy for solving mathematical problems. This finding also supports the results of research by Anandaraj \& Ramesh (2014), (Kozikoğlu, 2019) and (Sümen \& Çalışıcı, 2016) which states that metacognitive skills have a close relationship with mathematical problem solving abilities.

\section{CONCLUSION AND SUGGESTION}

Based on the research' results, it shows that the problem-solving abilities of students who have high mathematical resilience and metacognition skills are better than other students. It can be concluded that Mathematical Resilience and metacognition skills have a very large influence on students' ability to solve mathematical problems.

Basically there are many other factors in students that can improve the ability to solve mathematical problems, this study has not revealed all of these factors. Therefore, suggestions for further research is to conduct research on other factors in students that can affect mathematical problem solving abilities. 
DOI: https://doi.org/10.24127/ajpm.v10i4.4366

\section{DAFTAR PUSTAKA}

Abrar, A. I. P. (2018). Jenis-Jenis Belajar Matematika. AlKhwarizmi: Jurnal Pendidikan Matematika Dan Ilmu Pengetahuan Alam, 3(1), 51-62. https://doi.org/10.24256/jpmipa.v 3i1.218

Aljaberi, N. M., \& Gheith, E. (2016). Pre-Service Class Teacher' Ability in Solving Mathematical Problems and Skills in Solving Daily Problems. Higher Education Studies, 6(3), 32. https://doi.org/10.5539/hes.v6n3p 32

Alzahrani, K. S. (2021). Metacognition and Its Role in Mathematics Learning: an Exploration of the Perceptions of a Teacher and Students in a Secondary School. International Electronic Journal of Mathematics Education, 12(3), 521-537. https://doi.org/10.29333/iejme/62 9

Amaliah, U., Robandi, B., \& Iriawan, S. B. (2019). Penerapan Model Pembelajaran Berbasis Masalah Untuk Meningkatkan Kemampuan Pemecahan Masalah Matematis Siswa Sekolah Dasar. Jurnal Pendidikan Guru Sekolah Dasar, 4(3), 380-389. https://doi.org/10.17509/jpgsd.v4i 3.22946

Anandaraj, S., \& Ramesh, C. (2014). A Study on the Relationship between Metacognition and Problem Solving Ability of Physics Major Students. Indian Journal of Applied Research, 4(5), 191-199. https://www.worldwidejournals.c om/indian-journal-of-appliedresearch-(IJAR)/article/a-studyon-the-relationship-between- metacognition-and-problem-

solving-ability-of-physics-majorstudents/MzgxNg==/?is $=1$

Anisah, \& Lastuti, S. (2018). Pengembangan Bahan Ajar berbasis HOTS untuk Meningkatkan Kemampuan Pemecahan Masalah Matematis Mahasiswa. Kreano: Jurnal Matematika Kreatif-Inovatif, 9(2), 191-197.

https://doi.org/10.15294/kreano.v 9i2.16341

Arta, I., Japa, I. G. N., \& Sudarma, I. K. (2020). Problem Based Learning Berbantuan Icebreaker Berpengaruh Terhadap Kemampuan Pemecahan Masalah Matematika. Mimbar PGSD Undiksha, 8(2), 264-272. https://ejournal.undiksha.ac.id/ind ex.php/JJPGSD/article/view/2543 5

Attami, D., Budiyono, B., \& Indriati, D. (2020). The mathematical problem-solving ability of junior high school students based on their mathematical resilience. Journal of Physics: Conference Series, $\quad 1469, \quad 012152$. https://doi.org/10.1088/17426596/1469/1/012152

Bluman, A. (2004). Math Word Problems Demystified: A SelfTeaching Guide. McGraw-Hill Professional.

Elita, G. S., Habibi, M., Putra, A., \& Ulandari, N. (2019). Pengaruh Pembelajaran Problem Based Learning dengan Pendekatan Metakognisi terhadap Kemampuan Pemecahan Masalah Matematis. Mosharafa: Jurnal Pendidikan Matematika, 8(3), 447-458.

http://journal.institutpendidikan.ac .id/index.php/mosharafa 
Febriyanti, C., \& Irawan, A. (2017). Meningkatkan Kemampuan Pemecahan Masalah dengan Pembelajaran Matematika Realistik. Delta-Pi: Jurnal Matematika Dan Pendidikan Matematika, 6(1), 31-41. http://ejournal.unkhair.ac.id/index .php/deltapi/article/view/350

Gurat, M. G. (2018). Mathematical problem-solving strategies among student teachers. Journal on Efficiency and Responsibility in Education and Science, 11(3), 5364.

https://doi.org/10.7160/eriesj.2018 .110302

Iskandar, S. M. (2014). Pendekatan Keterampilan Metakognitif Dalam Pembelajaran Sains Di Kelas. Erudio Journal of Educational Innovation, 2(2), 13-20. https://doi.org/10.18551/erudio.22.3

Jana, P., \& Fahmawati, A. A. N. (2020). Model Discovery Learning Untuk Meningkatkan Kemampuan Pemecahan Masalah. AKSIOMA: Jurnal Program Studi Pendidikan Matematika, $\quad 9(1), \quad 213$. https://doi.org/10.24127/ajpm.v9i 1.2157

Johnston-Wilder, S., Clare, L., Brindley, J., \& E., G. (2015). Developing Mathematical Resilience In School-Students Who Have Experienced Repeated Failure. 8th Annual International Conference of Education, Research and Innovation (ICERI2015).

Johnston-Wilder, S., \& Lee, C. (2014). Developing Mathematical Resilience. BERA Annual Conference 2010, 51(06). http://oro.open.ac.uk/24261/2/3C2 3606C.pdf
Kozikoğlu, İ. (2019). Investigating critical thinking in prospective teachers: Metacognitive skills, problem solving skills and academic self-efficacy. Journal of Social Studies Education Research, 10(2), 111-130. https://www.learntechlib.org/p/21 6567/

Kristianto, D., \& Rahayu, T. S. (2020). Pengembangan Media Pembelajaran E-Komik untuk Meningkatkan Kemampuan Pemecahan Masalah Matematika Kelas IV. Jurnal Pendidikan Tambusai, 4(19), 939-946. https://www.jptam.org/index.php/j ptam/article/view/553

Lestari, F., Marta, R., \& Indah, V. (2020). Penerapan Model Pembelajaran Probing Prompting untuk Meningkatkan Kemampuan Pemecahan Masalah Matematis. Journal on Teacher Education, 2(1), 247-255. https://doi.org/10.31004/jote.v2i1. 1225

Liljedahl, P., Santos-Trigo, M., Malaspina, U., \& Bruder, R. (2016). Problem Solving in Mathematics Education. https://doi.org/10.1007/978-3319-40730-2_1

Marlina, R., Nurjahidah, S., Sugandi, A. I., \& Setiawan, W. (2018). Penerapan Pendekatan Problem Based Learning Untuk Meningkatkan Kemampuan Pemecahan Masalah Matematis Siswa Kelas Vii Mts Pada Materi Perbandingan Dan Skala. JPMI (Jurnal Pembelajaran Matematika Inovatif), 1(2), 113. https://doi.org/10.22460/jpmi.vli2 .p113-122

Muhammad, G. M., Septian, A., \& Sofa, M. I. (2018). Penggunaan 
DOI: https://doi.org/10.24127/ajpm.v10i4.4366

Model Pembelajaran Creative Problem Solving untuk Meningkatkan Kemampuan Pemecahan Masalah Matematis Siswa. Mosharafa: Jurnal Pendidikan Matematika, 7(3), 315-326.

https://doi.org/10.31980/mosharaf a.v7i3.140

Nasution, M. D., Oktaviani, W., Muhammadiyah, U., Utara, S., Muhammadiyah, U., \& Utara, S. (2017). Berbasis Masalah Untuk Meningkatkan Kemampuan Pemecahan Masalah Siswa Smp Pab 9 Klambir V T . P. Jurnal Iqra': Kajian Ilmu Pendidikan, 1(2), $\quad$ 46-55. http://jurnal.umsu.ac.id/index.php/ jmes/article/view/4390

Nikmah, N., Rahayu, R., \& Fajrie, N. (2020). Penerapan Media Pembelajaran Math Mobile Learning Untuk Meningkatkan Kemampuan Pemecahan Masalah Siswa Kelas IV. WASIS: Jurnal Ilmiah Pendidikan, 1(2), 44-52. https://doi.org/10.24176/wasis.v1i 2.4895

Noviantii, E., Yuanita, P., \& Maimunah, M. (2020). Pembelajaran Berbasis Masalah dalam Meningkatkan Kemampuan Pemecahan Masalah Matematika. Journal of Education and Learning Mathematics Research (JELMaR), 1(1), 65-73. https://doi.org/10.37303/jelmar.v1 i1.12

Osman, S., Che Yang, C. N. A., Abu, M. S., Ismail, N., Jambari, H., \& Kumar, J. A. (2018). Enhancing Students' Mathematical ProblemSolving Skills through Bar Model Visualisation Technique. International Electronic Journal of Mathematics Education, 13(3), 273-279. https://doi.org/10.12973/iejme/39 19

Peña-Ayala, A., \& Cárdenas, L. (2015). A Conceptual Model of the Metacognitive Activity. In Metacognition: Fundaments, Applications, and Trends (pp. 3972). Springer. https://doi.org/10.1007/978-3319-11062-2_3

Polya, G. (2004). How to solve it: A new aspect of mathematical method. Princeton university press.

https://books.google.com/books?h $\mathrm{l}=\mathrm{id} \& \mathrm{lr}=\& \mathrm{id}=\mathrm{z}$ hssbu9kyQQC\&oi $=$ fnd $\& p g=P P 2 \& d q=H o w+$ to + Solv $\mathrm{e}+\mathrm{It} \& \mathrm{ots}=\mathrm{oZlKRqpTS} \& \& \operatorname{sig}=\mathrm{y} 2 \mathrm{a}$ oI8syqFgLoV1ZOcfK4GDly0I

Psycharis, S., \& Kallia, M. (2017). The effects of computer programming on high school students' reasoning skills and mathematical self-efficacy and problem solving. Instructional Science, 45(5), 583602.

https://doi.org/10.1007/s11251017-9421-5

Pujiank, S., Jamaluddin, \& Hadiprayitno, G. (2016). Kemampuan Metakognisi Mahasiswa Program Studi Pendidikan Biologi. Jurnal Pendidikan: Teori, Penelitian, Dan Pengembangan, 1(10), 20162022.

http://journal.um.ac.id/index.php/j ptpp/article/view/7413/3367

Putri, R. S., Suryani, M., \& Jufri, L. H. (2019). Pengaruh Penerapan Model Problem Based Learning terhadap Kemampuan Pemecahan Masalah Matematika Siswa. Mosharafa: Jurnal Pendidikan Matematika, 8(2), 331-340. https://doi.org/10.31980/mosharaf a.v8i2.471 
Qamardhani, N. A., \& Surya, E. (2018). Efektifvitas Penggunaan Metode Guided Discovery dalam Meningkatkan Kemampuan Pemecahan Masalah Matematika. Jurnal Sinastekmapan, 1, 12421249.

http://portaluniversitasquality.ac.i d:590/sinastekmapan/index.php/si nastekmapan/article/view/215

Rahmiati, R., Musdi, E., \& Fauzi, A. (2018). Pengembangan Perangkat Pembelajaran Matematika Berbasis Discovery Learning Untuk Meningkatkan Kemampuan Pemecahan Masalah Siswa Kelas VIII SMP. Mosharafa: Jurnal Pendidikan Matematika, 6(2), 267-272. https://doi.org/10.31980/mosharaf a.v6i2.314

Rott, B. (2020). Teachers' Behaviors, Epistemological Beliefs, and Their Interplay in Lessons on the Topic of Problem Solving. International Journal of Science and Mathematics Education, 18(5), 903-924. https://doi.org/10.1007/s10763019-09993-0

Sariningsih, R., \& Purwasih, R. (2017). Pembelajaran Problem Based Learning Untuk Meningkatkan Kemampuan Pemecahan Masalah Matematis Dan Self Efficacy Mahasiswa Calon Guru. JNPM (Jurnal Nasional Pendidikan Matematika), $\quad 1(1), \quad 163$. https://doi.org/10.33603/jnpm.v1i 1.275

Saygilı, S. (2017). Examining the problem solving skills and the strategies used by high school students in solving non-routine problems. E-International Journal of Educational Research, 8(2), 91-114. https://dergipark.org.tr/en/downlo ad/article-file/338828

Schoenfeld, A. H. (2013). Reflections on problem solving theory and practice. The Mathematics Enthusiast, 10(1), 9-34. https://scholarworks.umt.edu/tme/ vol10/iss 1/3/

Sejati, K. A. P., \& Koeswanti, H. D. (2020). Pengembangan Model Media Pembelajaran Berbasis PC Game Untuk Meningkatkan Kemampuan Pemecahan Masalah Materi Bangun Datar. Jurnal Cendekia: Jurnal Pendidikan Matematika, 4(2), 602-614. https://doi.org/10.31004/cendekia. v4i2.279

Sharp, E., \& Shih Dennis, M. (2017). Model Drawing Strategy for Fraction Word Problem Solving of Fourth-Grade Students With Learning Disabilities. Remedial and Special Education, 38(3), 181-192.

https://doi.org/10.1177/07419325 16678823

Sintawati, M., Berliana, L., \& Supriyanto, S. (2020). Real Mathematics Education (Rme) Untuk Meningkatkan Hasil Belajar Dan Kemampuan Pemecahan Masalah Matematika Siswa Sekolah Dasar. PeTeKa, 3(1), 26-33. http://jurnal.umtapsel.ac.id/index.php/ptk/article/v iew/1539

Sumartini, T. S. (2018). Peningkatan Kemampuan Pemecahan Masalah Matematis Siswa melalui Pembelajaran Berbasis Masalah. Mosharafa: Jurnal Pendidikan Matematika, 5(2), 148-158. https://doi.org/10.31980/mosharaf a.v5i2.270

Sumen, Ö. Ö., \& Çalışıcı, H. (2016). The Relationships Between 
DOI: https://doi.org/10.24127/ajpm.v10i4.4366

Preservice Teachers'

Mathematical Literacy Self Efficacy Beliefs, Metacognitive Awareness And Problem Solving Skills. Participatory Educational Research, spil6(2), 11-19. https://doi.org/10.17275/per.16.sp i. 2.2

Surya, E., \& Putri, F. A. (2017). Improving mathematical problemsolving ability and self-confidence of high school students through contextual learning model. Journal on Mathematics Education, 8(1), 85-94. https://eric.ed.gov/?id=EJ1173627

Tambunan, H. (2019). The Effectiveness of the Problem Solving Strategy and the Scientific Approach to Students' Mathematical Capabilities in High Order Thinking Skills. International Electronic Journal of Mathematics Education, 14(2). https://doi.org/10.29333/iejme/57 15

Taplin, M. (2004). Mathematics through problem solving. Institute of Sathya Sai Education, Hong Kong; Citeseer. https://citeseerx.ist.psu.edu/viewd oc/download?doi=10.1.1.1084.39 $52 \&$ rep $=$ rep $1 \&$ type $=$ pdf

Utami, R. E., Nugroho, A. A., Dwijayanti, I., \& Sukarno, A. (2018). Pengembangan E-Modul Berbasis Etnomatematika Untuk Meningkatkan Kemampuan Pemecahan Masalah. JNPM (Jurnal Nasional Pendidikan Matematika), 2(2), 268. https://doi.org/10.33603/jnpm.v2i 2.1458

Verschaffel, L., \& De Corte, E. (1993). A decade of research on word problem solving in Leuven: Theoretical, methodological, and practical outcomes. Educational Psychology Review, 5(3), 239256.

https://doi.org/10.1007/BF013230 46

Wicaksono, B., \& Akhdinirwanto, R. W. (2013). Peningkatan Kemampuan Metakognitif Fisika Melalui Model Pembelajaran Problem Based Learning Pada SMK Pancasila 1 Kutoarjo MS ID IS IK. Radiasi: Jurnal Berkala Pendidikan Fisika, 3(2), 182-185. Wilson, J. W., Fernandez, M. L., \& Hadaway, N. (2011). Mathematical Problem Solving. The University of Georgia. http://jwilson.coe.uga.edu/emt725 /PSsyn/Pssyn.html

Young-Loveridge, J. (2010). Two Decades of Mathematics Education Reform in New Zealand: What Impact on the Attitudes of Teacher Education Students?. Mathematics Education Research Group of Australasia.

https://eric.ed.gov/?id=ED521017

Yustianingsih, R., Syarifuddin, H., \& Yerizon, Y. (2017). Pengembangan Perangkat Pembelajaran Matematika Berbasis Problem Based Learning (PBL) untuk Meningkatkan Kemampuan Pemecahan Masalah Peserta Didik Kelas VIII. JNPM (Jurnal Nasional Pendidikan Matematika), $\quad$ 1(2), 258. https://doi.org/10.33603/jnpm.v1i 2.563 